\title{
Funds Management In Banks: A Cost-Benefit Perspective
}

M. R. Shollapur, Siddaganga Institute of Technology, India Y. G. Baligatti, K.R.C.E's Degree College, India

\begin{abstract}
The Indian banking witnessed a paradigm shift in their operations after the financial sector reforms in 1991. These reforms led to the emergence of new banks, new instruments, new methods of doing business, and finally heightened competition in the banking industry. In this context, it is imperative on the part of the Indian banking industry to strengthen financial base, increase overall efficiency, and improve profitability by designing appropriate funds management policies and practices. This paper examines the profitability of funds management of the select Indian banks with a cost-benefit perspective.
\end{abstract}

\section{INTRODUCTION}

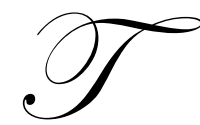

he key to a bank's success is the selection of sources and uses of funds. The source consists of capital funds, deposits and borrowings. Capital funds are the owned funds that serve as a protection against risk and insolvency. Similarly, deposits are the primary source of bank funds. The size of the deposits determines the funds available for profitable deployment. In addition, banks borrow funds from time to time in the money market to meet the temporary deficiency as well as to expand their assets. All these funds are to be deployed in various avenues considering the risk and return factors. These avenues are, however, not alike in their returns. The assets, such as cash in hand, balance with Reserve Bank of India (RBI), money at call and short notice, are held as per the liquidity requirements, and the return on these funds is almost zero, except money at call and short notice. Investments under Statutory Liquidity Ratio (SLR) serve the purpose of liquidity as well as income. The rate of return on such investments should be adequate enough to cover financial and operating costs. Further, lending is a significant area of employment of funds in terms of size of funds involved as well as quantum of revenue generated. However, it carries a high degree of credit risk. In addition, banks also use a portion of their funds for creating their business infrastructure which facilitates an enabling environment to conduct business and generate income.

Efficient management of funds essentially includes raising of funds and their use in the manner that generates revenues sufficient to meet the operational as well as financial costs and contributes a reasonable return on capital. Thus, the objective of earning profits shall be fulfilled by an appropriate design of funds management on sound commercial principles. This thinking necessitated to conduct a study on cost-benefit analysis of bank funds. The development of an analytical framework for cost-benefit approach to funds management was based on a comprehensive review of literature.

\section{REVIEW OF LITERATURE}

Laxman (1985) analyzed the problem of decline in profitability of banks in India and recommended for mobilization of potential deposits through special deposit mobilization cell, judicious borrowings, control on mounting over-dues, and construction of professional investment portfolio to increase the profitability and liquidity. Kishore Anil (1987) has underscored the need for effective funds management in banks in the light of rising operative expenses, cost of deposits, mounting overdues, and soaring social expectations. Maintenance of low cash balance, careful credit appraisal and regular monitoring of advances, cost-benefit approach towards all banking transactions are the important recommendation of the study. Peter S Rose (1987) found that the banks across the world today are facing a crucial challenge in raising and using of funds. He suggested for short-term borrowings in 
the domestic money markets, selling old loans, and securitizing loans and other assets, focusing on innovations and new techniques for mobilization of funds. Alberto, Lapuz and Glenn (1989) suggested for changes in deposit and loan mix for improving the banks' profitability. Udeshi (1989) observed that funds management has become difficult due to large network of branches, diversified business and increasing competition among banks. Khannan (1993) emphasized on stable call money rates, switching across the short dated and long dated securities on the basis of yield, planned growth of deposits with favorable mix, etc., for the effective management of bank funds. Mishra (1993) stressed on better credit mix, deposit mix, increase in non-fund revenue and control over non-performing assets for improving the banks' profitability. Verma and Malahotra (1993) suggested for improvement in capital base of the banks, expansion of bank resource base, tapping the deposits from rural and semi urban areas and deploying them profitably. Toor (1994) analyzed the various sources and uses of funds with risk-return perceptive and found that the composition of funds and their deployment are important in determining the operational efficiency of banks. Prashanta Athma and Obul Reddy (1997) suggested for focusing on interest and discount income that constitute more than $80 \%$ of the total income of the banks. Bhairav Desai and Mayuri (2000) viewed that it is the efficiency with which the management handles the available lendable funds that determines its survival and status in the banking industry. Vidwans and Kaveri (2001) found that a significant reduction in non-performing assets (NPAs) and cost reduction in operations are instrumental for improvement in bank's profitability. Uppal (2007) found that banks would benefit if they were to mobilize funds through borrowings rather than public deposits. Thus the review reveals that the funds management in banks is examined by the researchers from different perspectives. A study on profitability of funds management with the cost and benefit perspective is found to be unexamined by the researchers. This focus on funds management is accomplished by the present study titled "Funds Management in Banks: A Cost-Benefit Perspective”.

\section{OBJECTIVES, SCOPE AND METHODOLOGY}

The objectives of the study are as follows:

1. To examine the cost of sources of funds

2. To analyze the return from deployment of funds

3. To trace the pattern of utilization of deposits and examine the underlying profitability of funds management.

The study is based on the data drawn from the annual reports of the 12 selected Public Sector Banks (PSBs) in India. It covers a period of eight years from 1999- 2000 to 2006-2007. The sources and uses of funds as represented by various items of liabilities and assets contained in balance sheets are considered for the purpose of analysis. Similarly, the items such as interest cost, interest income, etc., are drawn from P\&L accounts of these banks.

The selection of the banks is based on the Report of Working Group (1999) constituted under the chairmanship of Shri M. S. Verma. This Group classified the banks on the basis of capital adequacy, coverage ratio, return on investment, net interest margin, ratio of operating profit to average working funds, ratio of cost to income, ratio of staff cost to the net interest income plus all other income. For the purpose of the present study the banks are reclassified as High Profile Banks (HPBs), Medium Profile Banks (MPBs) and Low Profile Banks (LPBs) based on their performance. In each category, four banks are randomly selected. They include Oriental Bank of Commerce, State Bank of Patiala, Punjab National Bank and Corporation Bank in the HPB segment. Andhra Bank, Bank of India, Bank of Maharastra and State Bank of India in the MPB segment, and UCO Bank, United Bank of India, Indian Bank and Indian Overseas Bank in the LPB segment. The relevant data of these banks have been aggregated for the purpose of analysis. The data are presented through tables and analyzed with the help of ratios, percentages, arithmetic means, standard deviation (Std. Dev) and coefficient of variation (C.V.). The analysis of each point is done from the point of view of banking industry as a whole as well as the segments such as HPB, MPB and LPB.

The inferences are drawn from the information contained in financial statements of the selected banks using the interrelated financial ratios. The size of the sample is adequate i.e.12 out of 27 PSBs in India. In addition, these selected banks represent the cross-section of the public sector banking industry as a whole belonging to high profile, medium profile and low profile segments. The period covered for the study (1999-2000 to 2006-07) is also a long 
one and therefore, the findings can be generalized for the entire banking industry in the sphere of management of funds.

The approach to cost benefit analysis of funds management in this paper is developed from three broad perspectives: cost approach, return approach and an integrated approach to funds management. In each perspective key financial indicators have been used. The indicators of cost approach to funds management include cost of deposits, cost of borrowings, and cost of total funds. Similarly, the indicators of return approach to funds management cover return on investments, and return on advances. Finally the ratios such as ratio of deposits to total liabilities, ratio of investments to deposits, and ratio of credit to deposits are used under integrated approach to funds management.

\section{ANALYSIS AND DISCUSSION}

\section{Cost of Deposits}

Deposits constitute a vital source of funds required for banking business. The components of deposit mix, such as fixed, current, and savings deposits, have their own risk-return profiles that affect the profitability of banks. Average cost of deposits, which is a percentage of interest cost to total deposits, can be used as an indicator for analysing the cost or efficiency of deposits of banks and the banks' overall profitability. The higher the ratio, lower will be the productivity of funds management and vice versa. A lower ratio has a positive impact on the banks' profitability. The information relating to cost of deposits of the banks covered in the study is given in Table 1.

Table 1: Cost of Deposits (Percentages)

\begin{tabular}{|c|c|c|c|c|}
\hline Year & HPBs & MPBs & LPBs & Industry \\
\hline 2000 & 7.99 & 7.56 & 8.47 & 8.01 \\
\hline 2001 & 7.40 & 7.28 & 7.59 & 7.42 \\
\hline 2002 & 7.05 & 7.17 & 7.23 & 6.15 \\
\hline 2003 & 6.30 & 6.49 & 6.49 & 5.33 \\
\hline 2004 & 5.19 & 5.42 & 5.38 & 4.63 \\
\hline 2005 & 4.50 & 4.68 & 4.72 & 4.60 \\
\hline 2006 & 4.49 & 4.59 & 4.73 & 4.93 \\
\hline 2007 & 5.09 & 4.68 & 5.03 & 48.50 \\
\hline Total & 47.99 & 47.86 & 49.64 & 6.06 \\
\hline Mean & 6.00 & 5.98 & 6.21 & 1.44 \\
\hline Std Dev & 1.37 & 1.28 & 23.29 & \\
\hline CV & 22.83 & 21.39 & & 22.41 \\
\hline
\end{tabular}

Source: Statistical tables relating to banks of various years

Table 1 reveals that the overall cost of deposits for the banking industry, as a whole, is $6.06 \%$ for the period of 8 years (2000-2007). The industry's average cost of deposits has maintained a decreasing trend throughout the study period. The segmental comparison reveals that the MPBs have registered the lowest cost of deposits (5.98\%) as compared to HPBs (6.0\%) and LPBs (6.21\%). However, the variation between MPBs and HPBs is marginal. It appears that the LPBs are incurring more costs on their deposits. It is interesting to note that all the three segments have experienced a declining trend in cost of deposits. The declining trend in the cost of deposits has a positive impact on the banks' profitability. The declining trend shall be attributed to declining interest rate scenario on deposits. In terms of consistency in performance, MPBs have maintained a consistency in their cost of deposits as compared to LPBs and HPBs. This is evidenced by their CV values: LPBs (23.29), HPBs (22.83), and MPBs (21.39).

\section{Cost of Borrowings}

Banks procure funds from time to time from money market to meet temporary deficiency. Purchased funds include inter-bank and short-term institutional liabilities and certificate of deposits. These funds are mobilized in 
national and international money markets. Since these markets are more competitive, the funds raised in such markets are more volatile than deposits. Hence, funding the assets through these sources would entail liquidity risk. Cost of borrowings which is calculated as a percentage of interest on borrowings to total borrowings reveals the efficiency of cost of borrowed funds. Higher the ratio, lower will be productivity of funds management. On the other hand, lower interest on borrowings has a positive impact on the banks. The information relating to cost of borrowings is given in Table 2 .

Table 2 reveals that the overall cost of borrowings for the entire banking industry is $5.82 \%$ over the study period. The industry wise cost of borrowings has shown a declining trend throughout the study period. The segmental comparison reveals that the HPBs have registered the lowest average cost of borrowings (4.22\%) as compared to MPBs (6.33\%) and LPBs (6.91\%). It is indicative of the HPBs' capability of raising borrowed funds at relatively competitive rates. It is interesting to note that all the three segments have experienced a declining trend. The declining trend shall be attributed to a favorable liquidity position in the call money market. The declining trend in the cost of borrowings has a positive impact on the banks' profitability. MPBs have maintained a consistency as compared to other segments. This is evident by their CV values: HPBs (58.10), MPBs (50.07), and LPBs (46.74). Relatively higher CV of HPBs revealed that these banks are aggressive in borrowing their business requirements and hence they incur higher costs.

Table 2: Cost of Borrowed Funds (Percentages)

\begin{tabular}{|c|c|c|c|c|}
\hline Year & HPBs & MPBs & LPBs & Industry \\
\hline 2000 & 6.00 & 10.50 & 9.37 & 8.62 \\
\hline 2001 & 6.83 & 11.66 & 11.77 & 10.08 \\
\hline 2002 & 8.00 & 6.92 & 10.91 & 8.61 \\
\hline 2003 & 1.83 & 4.90 & 5.12 & 3.95 \\
\hline 2004 & 1.64 & 3.25 & 4.56 & 3.15 \\
\hline 2005 & 2.82 & 3.25 & 3.90 & 3.32 \\
\hline 2006 & 4.30 & 4.88 & 5.54 & 4.91 \\
\hline 2007 & 2.36 & 5.28 & 4.14 & 3.93 \\
\hline Total & 33.76 & 50.63 & 55.29 & 46.56 \\
\hline Mean & 4.22 & 6.33 & 6.91 & 5.82 \\
\hline Std Dev & 2.45 & 3.17 & 3.23 & 2.81 \\
\hline CV & 58.10 & 50.07 & 46.74 & \\
\hline
\end{tabular}

Source: Statistical tables relating to banks of various years

\section{Cost of Total Funds}

Behaviour of profitability of funds essentially depends on cost of funds. Cost of funds includes the hiring costs of funds such as interest on deposits and borrowings. Composition of these liabilities and the respective interest rates on each component influence the total cost of funds. Higher the ratio, lower will be the productivity of funds management and vice versa. The information relating to cost of total funds is given in Table 3 .

Table 3 reveals that the overall total cost of funds for the banking industry, as a whole, is $6.05 \%$ over the study period. The industry wise total cost of funds has shown a declining trend. The segmental comparison reveals that the HPBs have registered the lowest average cost of deposits (5.94\%) as compared to MPBs (6.01\%) and LPBs $(6.22 \%)$. In terms of maintaining a consistency in cost of funds, MPBs have maintained a greater consistency as compared to HPBs and LPBs. This is evidenced by their CV values: MPBs (21.6), HPBs (23.11), and LPBs (23.5). The declining trend in cost of total funds has a positive impact on the banks profitability. The declining trend in total cost of deposits shall be attributed to decline in both the cost of deposits as well as borrowings due to soft interest rate scenario and better liquidity position of the banks. 
Table 3: Cost of Total Funds (Percentages)

\begin{tabular}{|c|c|c|c|c|}
\hline Year & HPBs & MPBs & LPBs & Industry \\
\hline 2000 & 7.95 & 7.63 & 8.50 & 8.03 \\
\hline 2001 & 7.36 & 7.39 & 7.64 & 7.46 \\
\hline 2002 & 6.98 & 7.18 & 7.28 & 7.14 \\
\hline 2003 & 6.18 & 6.48 & 6.48 & 5.38 \\
\hline 2004 & 5.11 & 5.38 & 5.38 & 4.29 \\
\hline 2005 & 4.45 & 4.65 & 4.72 & 4.61 \\
\hline 2006 & 4.47 & 4.63 & 4.75 & 4.92 \\
\hline 2007 & 4.99 & 4.76 & 5.01 & 48.44 \\
\hline Total & 47.49 & 48.09 & 41.24 & 6.05 \\
\hline Mean & 5.94 & 6.01 & 6.22 & 1.46 \\
\hline Std Dev & 1.37 & 1.30 & 23.53 & \\
\hline CV & 23.11 & 21.62 & & 22.68 \\
\hline
\end{tabular}

Source: Statistical tables relating to banks of various years.

\section{Return on Investments}

Employment of bank funds in investments is intended to meet the requirements of statutory liquidity ratio (SLR). This serves two-fold purposes: maintaining liquidity needs and earning a fair return with limited risk. Thus, return on investment is a key factor in determining banks' profitability. The return on investments reveals the impact of movements of market interest rates on the portfolio value. A lower ratio indicates poor return on investments that adversely affects the profitability of funds management and vice versa. The information relating to return on investments is given in Table 4.

Table 4: Return on Investments (Percentages)

\begin{tabular}{|c|c|c|c|c|}
\hline Year & HPBs & LPBs & MPBs & Industry \\
\hline 2000 & 12.40 & 11.62 & 12.72 & 12.24 \\
\hline 2001 & 11.82 & 11.07 & 11.48 & 11.45 \\
\hline 2002 & 11.50 & 10.68 & 10.93 & 11.04 \\
\hline 2003 & 10.58 & 9.59 & 10.20 & 10.12 \\
\hline 2004 & 9.64 & 8.94 & 9.27 & 9.29 \\
\hline 2005 & 8.58 & 8.21 & 8.56 & 8.45 \\
\hline 2006 & 8.33 & 7.89 & 8.33 & 7.18 \\
\hline 2007 & 7.74 & 7.52 & 7.04 & 78.53 \\
\hline Total & 80.57 & 75.51 & 9.94 & 9.82 \\
\hline Mean & 10.07 & 9.44 & 1.68 & \\
\hline Std Dev & 1.76 & 1.55 & 16.89 & 1.66 \\
\hline CV & 17.45 & 16.41 & & \\
\hline
\end{tabular}

Source: Statistical tables relating to banks of various years

Table 4 reveals that the return on investments for the banking industry, as a whole, is $9.82 \%$. The industry wise return on investment has shown a gradual decline throughout the study period. The segmental comparison reveals that the HPBs have demonstrated a higher average return on investments (10.07\%) as compared to LPBs $(9.94 \%)$ and MPBs (9.44\%). The striking observation is that all the segments have registered a declining trend in the return on investments. This trend obviously tends to adversely impact on the profitability of banks. Among the three segments, MPBs have maintained consistency in return on investments as compared to HPBs and LPBs. This is evidenced by their CV values: MPBs (16.41), LPBs (16.89), and HPBs (17.45).

\section{Return on Advances}

A major share of banks' revenue emanates from return on advances. Return on advances includes interest and discount on various loans and advances such as cash credits, overdrafts, term-loans, bills purchased and 
discounted. Ratio of return on advances to total advances indicates the ability of banks in generating income from its lending operations. Higher the ratio of return on advances, higher will be the productivity of funds management and vice versa. A lower return on advances signifies poor return on advances or higher losses in loans. The information relating to return on advances is given in Table 5 .

Table 5 reveals that the overall return on advances, as a whole, is $9.67 \%$ for the study period. The industry wise return on advances has shown a declining trend during the first 6 years followed by a gradual increase during the latter part of the study period. The segmental comparison reveals that all the segments have shown declining trend throughout the study period barring the last two years. This trend reveals the declining income from lending operations that in turn affects banks' profitability of funds. The declining trend shall be attributed to declining interest rate scenarios. Among them, LPBs have registered relatively higher return (9.92\%) as compared to HPBs (9.57\%) and LPBs (9.51\%). This improvement in LPBs can be attributed to their increasing volume of credit business during the latter part of the study period. It is evident from the marked improvement in their credit deposit ratio from $45 \%$ to $65 \%$. It is interesting to note that LPBs have maintained consistency in return on advances as compared to HPBs and MPBs. This is indicated by their CV values: LPBs (13.55), HPBs (16.09), and LPBs (16.27).

Table 5: Return on Advances (Percentages)

\begin{tabular}{|c|c|c|c|c|}
\hline Year & HPBs & MPBs & LPBs & Industry \\
\hline 2000 & 11.74 & 11.78 & 12.31 & 11.94 \\
\hline 2001 & 11.43 & 11.38 & 11.17 & 11.32 \\
\hline 2002 & 10.57 & 10.37 & 10.51 & 10.48 \\
\hline 2003 & 9.81 & 9.75 & 10.08 & 9.88 \\
\hline 2004 & 8.46 & 8.30 & 9.07 & 8.61 \\
\hline 2005 & 7.90 & 7.78 & 8.58 & 8.09 \\
\hline 2006 & 7.93 & 8.03 & 8.53 & 8.17 \\
\hline 2007 & 8.73 & 8.67 & 9.15 & 7.85 \\
\hline Total & 76.56 & 76.06 & 79.40 & 7.34 \\
\hline Mean & 9.57 & 9.51 & 9.92 & 9.67 \\
\hline Std Dev & 1.54 & 1.55 & 1.34 & 1.47 \\
\hline CV & 16.09 & 16.27 & 13.55 & \\
\hline
\end{tabular}

Source: Statistical tables relating to banks of various years

\section{Ratio of Deposits to Total Liabilities}

The size of deposits determines the funds available for profitable deployment by banks. Deposits are mobolised in local markets which serve as a stable source of financing. Further, the deposits can be obtained at lower cost of financing when compared to the alternative sources of bank funds. Hence, it is important to know the share of deposits in the total sources of bank funds such as borrowings. Higher ratio of deposits to total liabilities indicates the banks' preference for deposits in their resource mobilisation. In addition, a higher share of deposits generally coexists with lower size of borrowings and vice versa. The information relating to percentage of total deposits to total liabilities is given in Table 6.

Table 6 reveals that the share of deposits in total liabilities of the banking industry, as a whole, is $84.38 \%$. The industry's ratio of deposits to total liabilities is almost stable at $84 \%$ without any wider fluctuations. The segmental comparison, however, reveals that the HPBs have maintained the lowest ratio (83.88\%) as compared to MPBs (84.38\%) and LPBs (85.27\%). The lower ratio of deposits to total liabilities of HPBs shall be attributed to the banks' ability to get funds in the call market having soft interest rates. In terms of consistency in deposit mobilization, LPBs have maintained a consistency of deposits in total liabilities (1.26) as compared to MPBs (1.33) and HPBs (2.44). 
Table 6: Total Deposits to Total Liabilities (Percentages)

\begin{tabular}{|c|c|c|c|c|}
\hline Year & HPBs & MPBs & LPBs & Industry \\
\hline 2000 & 80.03 & 85.05 & 83.32 & 85.05 \\
\hline 2001 & 87.04 & 85.71 & 84.18 & 85.71 \\
\hline 2002 & 84.22 & 85.17 & 85.21 & 85.17 \\
\hline 2003 & 85.57 & 84.29 & 85.49 & 84.29 \\
\hline 2004 & 84.00 & 82.21 & 85.77 & 82.21 \\
\hline 2005 & 83.65 & 83.55 & 86.04 & 83.55 \\
\hline 2006 & 82.66 & 85.05 & 86.74 & 85.05 \\
\hline 2007 & 83.89 & 84.04 & 85.38 & 84.04 \\
\hline Total & 671.06 & 675.05 & 682.13 & 875.05 \\
\hline Mean & 83.88 & 84.38 & 85.27 & 84.38 \\
\hline Std Dev & 2.05 & 1.12 & 1.07 & 1.12 \\
\hline CV & 2.44 & 1.33 & 1.26 & \\
\hline
\end{tabular}

Source: Statistical tables relating to banks of various years

\section{Ratio of Investments to Deposits}

Banks have to invest a portion of their deposits in government and corporate securities which earn relatively low income as compared to investments on loans and advances. A higher ratio of investment to deposits indicates that more funds are deployed in low return investments than in high return credit business. It also implies that the funds are diverted from credit business to investment activities for liquidity purpose than to earn a handsome return. This tends to adversely affect on the profitability of bank funds. The information relating to ratio of investments to deposits is given in Table 7.

Table 7: Ratio of Investments to Deposits (Percentages)

\begin{tabular}{|c|c|c|c|c|}
\hline Year & HPBs & MPBs & LPBs & Industry \\
\hline 2000 & 46.26 & 47.57 & 50.37 & 48.07 \\
\hline 2001 & 43.17 & 47.96 & 50.22 & 47.11 \\
\hline 2002 & 43.91 & 46.94 & 51.06 & 47.30 \\
\hline 2003 & 47.26 & 49.82 & 52.72 & 49.93 \\
\hline 2004 & 47.63 & 49.47 & 52.38 & 49.83 \\
\hline 2005 & 42.90 & 45.67 & 47.46 & 45.34 \\
\hline 2006 & 34.45 & 38.14 & 42.21 & 38.26 \\
\hline 2007 & 32.30 & 32.92 & 39.65 & 34.96 \\
\hline Total & 337.87 & 358.47 & 386.05 & 360.80 \\
\hline Mean & 42.23 & 44.81 & 48.26 & 45.10 \\
\hline Std Dev & 5.78 & 6.04 & 4.85 & 10.04 \\
\hline CV & 13.69 & 13.49 & & 5.52 \\
\hline Statis & & \\
\hline
\end{tabular}

Source: Statistical tables relating to banks of various years

Table 7 reveals that the ratio of investments to deposits for the entire banking industry is $45.10 \%$ for the study period. It ranges between $45 \%$ to $50 \%$ during the first six years followed by a significant decline in this ratio during the latter period of the study. The segmental comparison of average ratios reveals that the HPBs have registered a lower investment deposit ratio (42.43\%) as compared to MPBs (44.81\%) and LPBs (48.26\%). The higher ratio of investment to deposits of LPBs reveals that the substantial amount of funds is tied up in the investments that yield a relatively lower return when compared to return on the advances. This tends to affect the overall profitability of banks. It is interesting to note that this ratio is showing a declining trend in all the segments during the latter part of the study period. In terms of consistency in performance, LPBs have maintained a consistency in this ratio as compared to other segments. This is evident by their CV values: LPBs (10.04), MPBs (13.49), and HPBs (13.69). 


\section{Ratio of Credit to Deposits}

Profitability of banks essentially depends on the volume of credit. Credit deposit ratio reveals the extent of deposit utilized for meeting the credit needs of the banks. Change in the volume of loan business causes a change in the size of profits. Credit business carries high risk as well as high return. A higher credit deposit ratio indicates the higher deployment of deposits for credit business and higher will be the productivity of funds. The information relating to credit to deposits (C/D ratio) is given in Table 8 .

Table 8: Credit to Deposits (Percentages)

\begin{tabular}{|c|c|c|c|c|}
\hline Year & HPBs & MPBs & LPBs & Industry \\
\hline 2000 & 50.24 & 45.08 & 39.81 & 45.04 \\
\hline 2001 & 51.55 & 47.03 & 45.40 & 47.99 \\
\hline 2002 & 55.92 & 51.08 & 46.53 & 51.18 \\
\hline 2003 & 55.29 & 52.55 & 44.69 & 50.84 \\
\hline 2004 & 56.75 & 53.67 & 45.72 & 52.05 \\
\hline 2005 & 59.40 & 58.77 & 52.65 & 56.94 \\
\hline 2006 & 66.95 & 66.16 & 61.37 & 64.83 \\
\hline 2007 & 70.53 & 70.79 & 65.56 & 68.96 \\
\hline Total & 466.62 & 445.12 & 401.72 & 437.82 \\
\hline Mean & 58.33 & 55.64 & 50.21 & 54.73 \\
\hline Std Dev & 7.10 & 9.02 & 8.96 & 8.31 \\
\hline CV & 12.18 & 16.22 & 17.84 & 15.19 \\
\hline
\end{tabular}

Source: Statistical tables relating to banks of various years

Table 8 reveals that the credit deposit ratio for the banking industry is around 55\%. It has shown an increasing trend throughout the study period. The segmental comparison reveals that the HPBs have registered a higher ratio of credit to deposits $(58.33 \%)$ as compared to MPBs $(55.64 \%)$ and LPBs $(50.21 \%)$. The increasing trend in the credit deposit ratio reflects the profitable utilization of deposits. This tends to have a positive impact on the banks' profitability. The lower credit deposit ratio of LPBs reflects an ineffective utilization of costly deposits which tends to affect the profitability of funds management of LPBs. It is interesting to observe that all the three segments have demonstrated an increasing trend in the credit deposit ratio. The table also reveals that the HPBs have maintained consistency in the credit deposit ratio as compared to other segments. This is evident by their CV values: HPBs (12.8\%), MPBs (16.22\%), and LPBs (17.84\%).

\section{CONCLUSION}

The study reveals that the overall cost of funds, in terms of cost of deposits, as well as borrowings for the banking industry, as a whole, has maintained a decreasing trend. HPBs have relatively performed better than MPBs and LPBs in reducing both the costs. This is attributed to HPBs' ability to get funds in the call money market by exploiting the opportunities of soft interest rates. Similarly, the analysis of components of return on funds reveals that both the return on advances, as well as investments, has maintained a decreasing trend. Among the three segments, HPBs have relatively improved their performance in return on investments. The return on advances has shown a decreasing trend during the first six years. Interestingly, the LPBs have registered a higher return than the other segments. The declining trend in the rate of investments and advances leads to squeezing of the spread. This thin margin between cost and return of funds can be attributed to the deregulation of interest rates as well as the competition among the various banks. With regard to funding of operations, it is evident that the banking industry has demonstrated its preference for deposits. Further, banks have shown consistent performance in deposit mobilization as indicated by the ratio of total deposits to total liabilities. Among the three segments, the LPBs have maintained a relatively higher ratio of deposits to total liabilities. With regard to utilization of deposits, the study reveals that more funds are put in credit business than investments. The average CD ratio and investments to deposits ratios are $55 \%$ and $45 \%$, respectively. In the light of these findings, the banks need to mobilize funds by exploiting the opportunities of soft interest rates in the call market. Further, the excessive investments in low earnings SLR securities should be diverted toward relatively profitable loans and advances. This could enable banks 
to maintain the standard credit deposit ratio of $60 \%$ against their current ratio of 55\%. In view of a declining spread, the banks need to explore the non-interest income generating activities.

\section{AUTHOR INFORMATION}

Dr. M R Shollapur is professor and director of Postgraduate Department of Management Studies and Research Centre, Siddaganga Institute of Technology, Tumkur, Karnataka (India). He holds a first class master's degree in commerce (M Com), Business Administration (MBA), and Ph.D. in banking and finance. He has served for 27 years in teaching in collegiate and university including Karnataka University, Dharwad and Marshall University, Huntington (USA). Dr. Shollapur has completed two funded research projects, guided $4 \mathrm{PhDs}$ and 2 M.Phils. His publications include five books and 47 papers. His areas of interest include accounting, banking and finance.

Dr. Y.G.Baligatti is Associate professor in the Department of Commerce, Kittur Rani Channamma Education Society's Degree College, Bailhongal, (Karnataka), India. He has been serving in this institution for the past for 28 years. He obtained his M.Com. and Ph.D from Karnatak University, Dharwad. His area of specialization is banking and finance. He has published many research papers in reputed national and international journals and has presented papers in national and international conferences. Dr. Baligatti has guided M.Phil dissertations and currently working on UGC funded research project on 'Customer Satisfaction in Banks: A Study of Public and Private Sector Banks'. $\mathrm{He}$ has also served as 'Associate NCC Officer' in the National Cadet Corps, the largest uniformed youth organizations of the world.

\section{REFERENCES}

1. Alberto, G., Lapuz, (1989). "Effective Treasury Management for Today’s Banking", Bankers Journal, Malaysia, Feb, 1989. p.7.

2. Bhairav H. Desai and Mayuri, (2000). "Concept of Break Even Analysis and Bank Profitability-A Case Study", The Indian Journal of Commerce, Vol.53, Nos.1\&2, Jan-June 2000. p 5.

3. Kaveri Bansal and Mona Bansal, (2009). "Global Financial Meltdown-Challenges and Opportunities for Banks", The Indian Banker, Volume IV No.4, April, 2009. p.34.

4. $\quad$ Kaveri, V.S., (2001). "Loan Default and Profitability of Banks", IBA Bulletin, Jan, 2001. p.7.

5. $\quad$ Khanna, K., (1993). "Issues in Funds Management", BTC Bulletin, 12(1), Jan, 1993. p.13.

6. $\quad$ Kishore Anil, (1987). "Resource Management in Banks", IBA Bulletin, Jan, 1987. p.12.

7. Laxman, (1985). "Problem of intermediation and financial/funds management in Indian banking sector", Unpublished Thesis, Karnatak University, Dharwad.

8. Mishra Kailash Chandra, (1993). "Management of Funds in Commercial Banks", Bank of India Bulletin, Dec, 1993, p-343.

9. Peter Rose, (1987). "The Quest for Funds: New Directions in a New Market", Canadian Banker, Sept-Oct, 1987. p.46.

10. Prashanta Athma and Obul Reddy, (1997). "Profitability in Nationalised Bank", The Indian Journal of Commerce, Vol. No.L 190, Part I Mar, 1997. p.51.

11. Sangeeta Arora and Supeer Kaur, (2006). "Financial Performance of Indian Banking Sector in Post Reforms Era", The Indian Journal of Commerce, Vol.59 No.1, Jan- Mar, 2006, p.96.

12. Toor, N.S., (1994). "Funds Management Policies in Banks: Challenging Tasks Ahead", PNB Monthly Review, May, 1994. p.265.

13. Udeshi, J.J., (1989). "Funds Management", The Banker, Aug, 1989. p.28.

14. Uppal R.K., (2007). "Cost-Benefit Analysis of Commercial Banks In the Global Age: Future Strategies for Fund Management”, Business Horizon- A Journal of Commerce and Economics, Vol.1 July-Dec, 2007. p.121.

15. Vidwans and Kaveri, (2001). "Pragati Bank- A Case Study", Vinimaya, Vol XXII No.3 Oct-Dec 2001. p.37.

16. Verma, H.L., and Malhotra, A.K., (1993). "Funds Management in Commercial Banks", Deep and Deep Publications, New Delhi, 1993. 
NOTES 